\title{
SYNTHESIS AND ANTIOXIDANT ACTIVITY OF A NEW 4-AMINOCOUMARIN DERIVATIVE
}

\author{
NOVICA RISTIĆ ${ }^{*}$, NIKO RADULOVIĆ ${ }^{2}$, BILJANA DEKIĆ ${ }^{1}$, MILENKO RISTIĆ1, \\ VIDOSLAV DEKIĆ ${ }^{1}$
}

${ }^{1}$ Faculty of Science and Mathematics, University of Priština, Kosovska Mitrovica, Serbia

${ }^{2}$ Department of Chemistry, Faculty of Sciences and Mathematics, University of Niš, Niš, Serbia

\begin{abstract}
Synthesis, spectral characterization, and evaluation of in vitro antioxidant activity of a new coumarin derivative, 4((1,3,4-thiadiazol-2-yl)amino)-3-nitro-2H-chromene-2-one, are described. The synthesis of the new product was performed in three reaction steps, with a good overall yield $(\mathbf{7 8 \%})$. The structure was corroborated by detailed spectral analysis, including the 1D and 2D NMR experiments $\left({ }^{1} \mathrm{H}\right.$ - and ${ }^{13} \mathrm{C}$ NMR; ${ }^{1} \mathrm{H}-{ }^{1} \mathrm{H}$ COSY, NOESY, HSQC, and $\mathrm{HMBC}$ ). The in vitro antioxidant activity was evaluated using the DPPH test. The synthesized compound possesses a good free-radical scavenging activity, $\mathrm{IC}_{50}=596.7 \pm 0.3 \mu \mathrm{g} / \mathrm{ml}$, and can serve as a model for the synthesis of similar compounds with promising antioxidant effects.
\end{abstract}

Keywords: Coumarin derivative, Spectral characterization, NMR spectroscopy, Antioxidant activity, DPPH.

\section{INTRODUCTION}

Coumarin (2H-chromen-2-one) belongs to the benzopyrones, a group of heterocyclic compounds which have a condensed benzene and $\alpha$-pyrone ring. These naturally occurring secondary metabolites enumerate about 1300 derivatives isolated from a number of plant species and bacteria (Venugopala et al., 2013). Coumarins are deriving the shikimic acid biosynthetic pathway. Some coumarin derivatives of natural origin already have a medical application, for example, novobiocin, warfarin, acenocoumarin and umbelliferone (Stefanachi et al., 2018). For decades, more efforts have been made to make similar coumarin derivatives by organic synthesis. These derivatives possess an exceptionally wide spectrum of pharmacological properties such as: anticancer (Nofal et al., 2000; Ayati et al., 2018), antiinflammatory (Bansal et al., 2013; Hadjipavlou-Litina et al., 2007), antibacterial (Naik et al., 2017; Zaki et al., 2012; Radulović et al., 2015) antiviral/anti-influenza (Kostova et al., 2006; Su et al., 2006; Yu et al., 2003; Yeh et al., 2010), antifungal (Pasqualotto et al., 2010; Al-Amiery et al., 2012), anti-Alzheimer (Anand et al., 2012; Piazzi et al., 2008), anticoagulant (Danis et al., 2010), and antioxidant (Kotaiah et al., 2014; Manojkumar et al., 2009; Fylaktakidou et al., 2004).

The interactions between the substituent and the coumarin core determined the biological activity of the molecule itself, which results in its selectivity. Differently substituted derivatives of nitrocoumarin have a remarkable range of selectivity and possess pronounced pharmacological effects like antibacterial (Vaso et al., 2010; Aiyelabola et al., 2017), cytotoxic (Aiyelabola et al., 2017), and antioxidant (Parfënov \& Smirnov, 1991). Some of them have significance in the treatment of kidney cancer cells (Finn et al., 2002) and in the study of enzyme kinetics.

\footnotetext{
* Corresponding author: risticnovica@ gmail.com CHEMISTRY
}

In the light of the mentioned studies of biologically active coumarins, as well as our previous work (Dekić et al., 2010; Dekić et al., 2010), in this research we put emphasis on the synthesis, assignment of ${ }^{1} \mathrm{H}$ and ${ }^{13} \mathrm{C}$ NMR spectral data from an interpretation of results of $2 \mathrm{D}\left({ }^{1} \mathrm{H}-{ }^{1} \mathrm{H}\right.$ COSY, NOESY, HSQC and $\mathrm{HMBC}$ ) experiments and evaluation of the antioxidant activity of a new 4-amino substituted-3-nitrocumarin derivative.

\section{EXPERIMENTAL}

\section{General chemistry}

Reagents and solvents used in this research (A.R. grade) were of Sigma Aldrich (USA), Merck (Germany), Fluka (Germany) and Acros Organics (Belgium). Melting points were determined on MPM-HV2 (Germany) instrument. Recording of IR spectra was carried out on Thermo Nicolet model 6700 FTIR (USA) instrument and HR-MS(EI) spectra were recorded on a JEOL Mstation JMS 700 instrument (Germany). The reaction progress and purity of synthesized compounds checked by TLC, using silica gel plates (Kiesel $60 \mathrm{~F}_{254}$, Merck). Visualization was performed by UV light or spraying the plates with $1: 1(\mathrm{v} / \mathrm{v})$ aqueous sulfuric acid and then heating. The absorbance was measured using a UV-1800 Shimadzu spectrophotometer.

\section{NMR measurement}

${ }^{1} \mathrm{H}$ NMR (400 MHz) and ${ }^{13} \mathrm{C}$ NMR (100.6 MHz) spectra were recorded on Bruker Avance III spectrometer (Switzerland) at $25^{\circ} \mathrm{C}$ in DMSO- $d_{6}$, using a TMS as an internal standard. Chemical shifts are reported in $\mathrm{ppm}(\delta)$ values relative to TMS $\left(\delta_{\mathrm{H}} 0 \mathrm{ppm}\right)$ in ${ }^{1} \mathrm{H}$ or signals of residual solvents in ${ }^{13} \mathrm{C}$ and heteronuclear 2D NMR spectra (residual DMSO- $d_{6} \delta_{\mathrm{H}} 2.54 \mathrm{ppm}$ and ${ }^{13} \mathrm{CD}_{3} \mathrm{SOCD}_{3} \delta_{\mathrm{C}} 40.45 \mathrm{ppm}$. The coupling constant $(J)$ are reported in Hz. Multiplicities of proton resonance are designated as singlet (s), broad singlet (brs), a doublet of doublets (dd), a 
doublet of doublets of doublets (ddd) and a triplet of doublets (td). 2D spectra $\left({ }^{1} \mathrm{H}-{ }^{1} \mathrm{H}\right.$ COSY, NOESY, HSQC, and HMBC) are performed on the same instrument with a standard pulse sequence.

\section{Synthesis}

\section{Synthesis of 4-hydroxy-3-nitrocoumarin (2)}

According to an already known procedure (Savel'ev et al., 1973), in suspension of 4-hydroxycoumarin (1) (5 g, $30.8 \mathrm{mmol})$ and glacial acetic acid $(20 \mathrm{ml})$ the mixture of $72 \% \mathrm{NHO}_{3}(3 \mathrm{ml})$ and glacial acetic acid $(2.6 \mathrm{ml})$ was added. The obtained suspension was heated on a water bath until all of 4hydroxycoumarin are dissolved and does not show the brown vapors of nitrogen oxides. After cooled on ice bath yellow precipitate is obtained, then filtered and washed with saturated solution of sodium-bicarbonate and absolute ethanol. Recrystallization from absolute ethanol gives yellow crystals of 4-hydroxy-3-nitrocoumarin (2) (yield 84\%, m.p. 171-172 ${ }^{\circ} \mathrm{C}$ ).

\section{Synthesis of 4-chloro-3-nitrocoumarin (3)}

In $N, N$-dimethylformamide ( $2 \mathrm{ml}, 26 \mathrm{mmol})$, cooled to $10^{\circ} \mathrm{C}$, during the $15 \mathrm{~min}$, with stirring, $\mathrm{POCl}_{3}(4 \mathrm{~g}, 26 \mathrm{mmol})$ was added. The reaction then continued at room temperature for another $15 \mathrm{~min}$. After the expiry of this period, 4-hydroxy-3nitrocoumarin (2) $(5.3 \mathrm{~g}, 26 \mathrm{mmol})$ dissolved in $\mathrm{N}, \mathrm{N}$ dimethylformamide $(12.5 \mathrm{ml})$ was added dropwise. The addition of cold water $(15 \mathrm{ml})$, after $15 \mathrm{~min}$, stopped the reaction. The resulting yellow precipitate was filtered and washed with saturated sodium bicarbonate and water, to obtain the final product of 4-chloro-3-nitrocoumarin (3) (yield 87\%, m.p. 162$163{ }^{\circ} \mathrm{C}$ ) as a yellow crystals (Kaljaj et al., 1987), by recrystallization from the benzene:hexane mixture $(1: 1, \mathrm{v} / \mathrm{v})$.

Synthesis of 4-((1,3,4-thiadiazol-2-yl)amino)-3-nitro-2Hchromen-2-one (5)

In the solution of 4-chloro-3-nitrocoumarin (3) (1 g, 4.4 $\mathrm{mmol})$ in $\mathrm{N}, \mathrm{N}$-dimethylformamide $(10 \mathrm{ml}), 1,3,4$-thiadiazol-2amine (4) $(0.45 \mathrm{~g}, 4.4 \mathrm{mmol})$ and sodium bicarbonate $(0.75 \mathrm{~g})$ was added. The mixture was stirred, and progress of the reaction was monitored by TLC. After $90 \mathrm{~min}$, reaction was stopped by the addition of $20 \mathrm{ml}$ of cold water. The formed light yellow solid precipitate was filtered and washed with water, to obtain 4 ((1,3,4-thiadiazol-2-yl)amino)-3-nitro-2H-chromen-2-one (5) as yellow fine powder (yield $78 \%$, m.p. $237-239{ }^{\circ} \mathrm{C}$ ). IR (neat): $3262(\mathrm{~N}-\mathrm{H}), 3066(\mathrm{Ar}-\mathrm{H}), 1745(\mathrm{C}=\mathrm{O}), 1606(\mathrm{C}=\mathrm{C}), 1543$ and $1339\left(\mathrm{NO}_{2}\right), 1284,1123,867,753 \mathrm{~cm}^{-1}$. HR-MS(EI): $\mathrm{M}^{+}$ $\left(\mathrm{C}_{11} \mathrm{H}_{6} \mathrm{~N}_{4} \mathrm{O}_{4} \mathrm{~S}\right)$ 290.0109, requires $290.0104(\Delta=+0.4 \mathrm{mmu})$.

\section{DPPH assay}

Antioxidant activity of synthesized compound (5) was determined by DPPH (2,2-diphenyl-1-picrylhydrazyl) using the previously described method with slight modification (Braca et al., 2001). In a test tube with $1 \mathrm{ml}$ of a methanolic solution of tested compound (1.96-1000 $\mu \mathrm{g} / \mathrm{ml}), 2 \mathrm{ml}$ of $0.004 \% \mathrm{DPPH}$ methanolic solution was added. Test tubes left to stand for 35 min. in the dark at room temperature. After the expiry of this period, absorbance was read at $517 \mathrm{~nm}$. The control was constituted by methanol instead of tested compounds. The same procedure was repeated for the solutions of ascorbic acid (1.96$1000 \mu \mathrm{g} / \mathrm{ml}$ ) which used as a standard. The percentage of inhibition of the DPPH radical was calculated using the equation (1):

$$
\% \text { of inhibition }=[(A c-A s) / A c] \cdot 100
$$

where $A c$ is the absorbance of control solution ( $2 \mathrm{ml}$ of DPPH radical and $1 \mathrm{ml}$ of methanol) and $A s$ is the absorbance of the methanolic solution of tested compound ( $2 \mathrm{ml} \mathrm{DPPH}$ and $1 \mathrm{ml}$ of a methanolic solution of the tested compounds). Results were expressed as $\mathrm{IC}_{50}$ values in $\mu \mathrm{g} / \mathrm{ml}$ (concentration of the tested compound required to decrease the initial DPPH concentration by $50 \%$ ) and estimated from $\%$ inhibition versus the concentration sigmoidal curve, using a non-linear regression algorithm.

\section{RESULTS AND DISCUSSION}

\section{Chemistry}

The synthesis of the new coumarin derivative was performed in three steps to give 4-((1,3,4-thiadiazol-2-yl)amino)3-nitro-2H-chromene-2-one (5) as the main product (Scheme 1). The structure of the obtained compound was confirmed by IR spectroscopy and HR-MS(EI), and also complete assignation of the ${ }^{1} \mathrm{H}$ and ${ }^{13} \mathrm{C}$ NMR spectra was performed, by combining the data obtained with $1 \mathrm{D}$ and $2 \mathrm{D}$ techniques NMR $\left({ }^{1} \mathrm{H}\right.$ and ${ }^{13} \mathrm{C}$ NMR, ${ }^{1} \mathrm{H}^{-}{ }^{1} \mathrm{H}$ COSY, NOESY, HSQC, and HMBC).

The IR spectrum of the synthesized compound showed the bands that confirm his structure. At 3262 and $3066 \mathrm{~cm}^{-1}$ appeared the bands of $\mathrm{N}-\mathrm{H}$ and $\mathrm{Ar}-\mathrm{H}$ bonds, respectively. The carbonyl group gives a strong vibration at $1745 \mathrm{~cm}^{-1}$, while the band characteristic of the $\mathrm{C}=\mathrm{C}$ bond occurs at $1606 \mathrm{~cm}^{-1}$. The nitro group showed two strong bands at 1339 and $1543 \mathrm{~cm}^{-1}$. The molecular weight based on HR-MS(EI) (290.0109) indicated the molecular formula of $\mathrm{C}_{11} \mathrm{H}_{6} \mathrm{~N}_{4} \mathrm{O}_{4} \mathrm{~S}$, which additionally confirmed the structure of this compound.

In the ${ }^{1} \mathrm{H}$ NMR spectrum of the synthesized compound appeared six signals, two doublet of doublets with chemical shifts at 7.56 and $8.10 \mathrm{ppm}$, one triplet of doublets at $7.49 \mathrm{ppm}$, one doublet of doublets of doublets at $7.67 \mathrm{ppm}$, one wide singlet at $9.25 \mathrm{ppm}$ and one singlet at $9.35 \mathrm{ppm}$ (Fig. 1). The assignment of these signals can be determined based on the position of the hydrogen atoms in the assumed structure. The singlet corresponds to hydrogen atoms from the ring of the substituent and the secondary amino group. Based on the shape of the signal 
(a wide singlet) can be concluded that the signal at $9.25 \mathrm{ppm}$

signal at $9.34 \mathrm{ppm}$ corresponds to the proton at the position $\mathrm{H}-5$ '.

corresponding to hydrogen bound to the nitrogen atom, so the

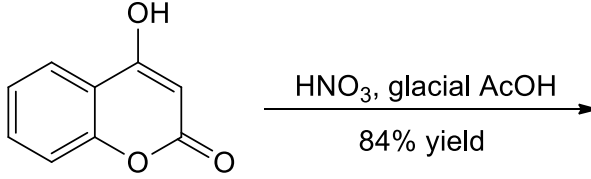

1<smiles>O=c1oc2ccccc2c(O)c1[N+](=O)[O-]</smiles>

2

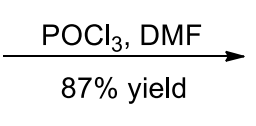<smiles>O=c1oc2ccccc2c(Cl)c1[N+](=O)[O-]</smiles>

3<smiles>Nc1nncs1</smiles>

3

4 
Assignments can be performed starting from the signal which showed correlation with the hydrogen from an amino group (9.25 ppm) and doublet of doublets at $8.10 \mathrm{ppm}$. Based on the spatial disposition in the molecule, it is clear that this signal belongs to the proton $\mathrm{H}-5$. The signal shape corresponding to the position of the proton in the molecule, since it is coupling with one vicinal $(\mathrm{H}-6, J=8.0 \mathrm{~Hz})$ and one distant $(\mathrm{N}-7, J=1.6 \mathrm{~Hz})$ proton. Signals of other protons, bound to the coumarin core are assigned based on their correlations in the NOESY spectrum, in a similar manner. Chemical shifts of the carbon atoms to which these protons are attached $(\mathrm{C}-5, \delta 123.3$; C-6, $\delta$ 125.7; C-7, $\delta$ 131.8; C-8, $\delta$ 118.0) were determined based on the HSQC spectrum. This assignation is in agreement with data obtained from the HMBC spectrum (correlation of hydrogen and carbon through three chemical bonds) (Fig. 4).

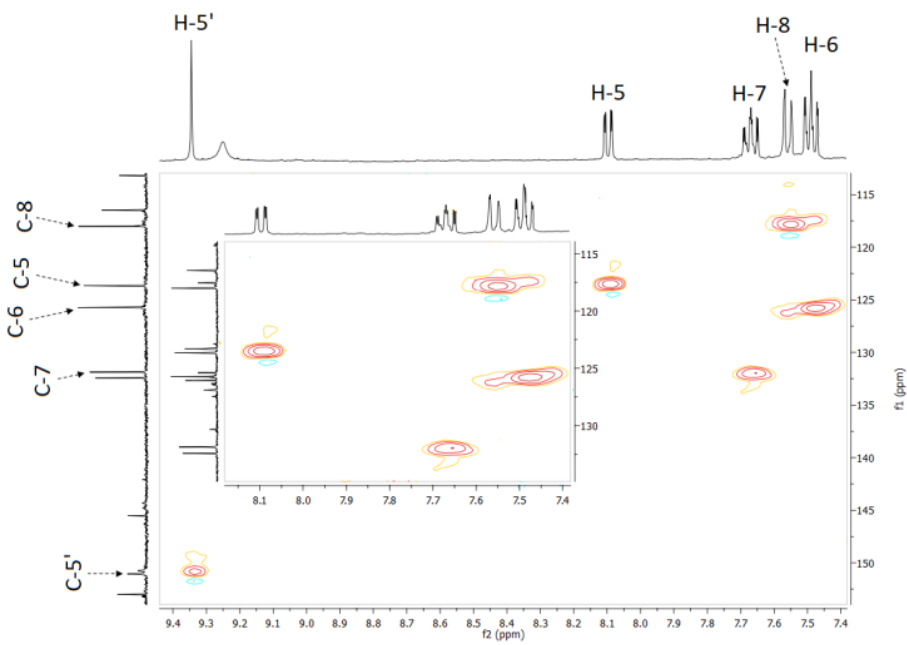

Figure 3. HSQC spectrum of compound (5).
Based on interactions with the H-5 in the same spectrum, the chemical shifts of quaternary carbons, C-4a and C-8a, 113.2 and $153.0 \mathrm{ppm}$, respectively, were assigned. Proton $\mathrm{H}-5$ in this spectrum showed a once more correlation, with the signal at 145.5 ppm, which assigned carbon at position C-4. The chemical shift of the only remaining quaternary carbon atom from the ring of the substituent, C-2' at 150.7 ppm (Table 1), was determined based on his HMBC correlation with the proton on position $\mathrm{H}-5$ '.

Table 1. NMR data of compound (5) recorded at $101\left({ }^{13} \mathrm{C}\right.$ NMR) and $400 \mathrm{MHz}\left({ }^{1} \mathrm{H} \mathrm{NMR}\right)$.

\begin{tabular}{|c|c|c|c|c|}
\hline Position & $\delta_{\mathrm{H}}, \mathrm{m}(J, \mathrm{~Hz})$ & $\delta_{\mathrm{C}}$ & NOESY* & $\mathrm{HMBC} * *$ \\
\hline 2 & & 154.4 & & \\
\hline 3 & & 116.5 & & \\
\hline 4 & & 145.5 & & \\
\hline $4 a$ & & 113.2 & & \\
\hline 5 & $\begin{array}{c}8.10 \mathrm{dd} \\
(1.6,8.0)\end{array}$ & 123.7 & H-6 & $\begin{array}{c}\text { C-4, C-7, } \\
\text { C-8a }\end{array}$ \\
\hline 6 & $\begin{array}{c}7.49 \mathrm{td} \\
(0.8,8.0)\end{array}$ & 125.7 & H-5, H-7 & C-4a, C-8a \\
\hline 7 & $\begin{array}{c}7.67 \mathrm{ddd} \\
(1.6,8.0,8.4)\end{array}$ & 131.9 & H-6, H-8 & $C-5, C-8 a$ \\
\hline 8 & $\begin{array}{c}7.56 \mathrm{dd} \\
(0.8,8.4) \\
\end{array}$ & 118.0 & $\mathrm{H}-7$ & $\begin{array}{c}\text { C-4a, C-6, } \\
\text { C-8a } \\
\end{array}$ \\
\hline $8 \mathrm{a}$ & & 153.0 & & \\
\hline $2^{\prime}$ & & 150.7 & & \\
\hline $\mathrm{N}-\mathrm{H}$ & $9.25 \mathrm{brs}$ & & & \\
\hline $5^{\prime}$ & $9.34 \mathrm{~s}$ & 151.1 & & $\mathrm{C}-2^{\prime}$ \\
\hline
\end{tabular}

*NOESY interactions of the hydrogen from the column "Position" with the hydrogen from the column "NOESY"

**HMBC interactions of the hydrogen from the column "Position" with the carbons from the column "HMBC"

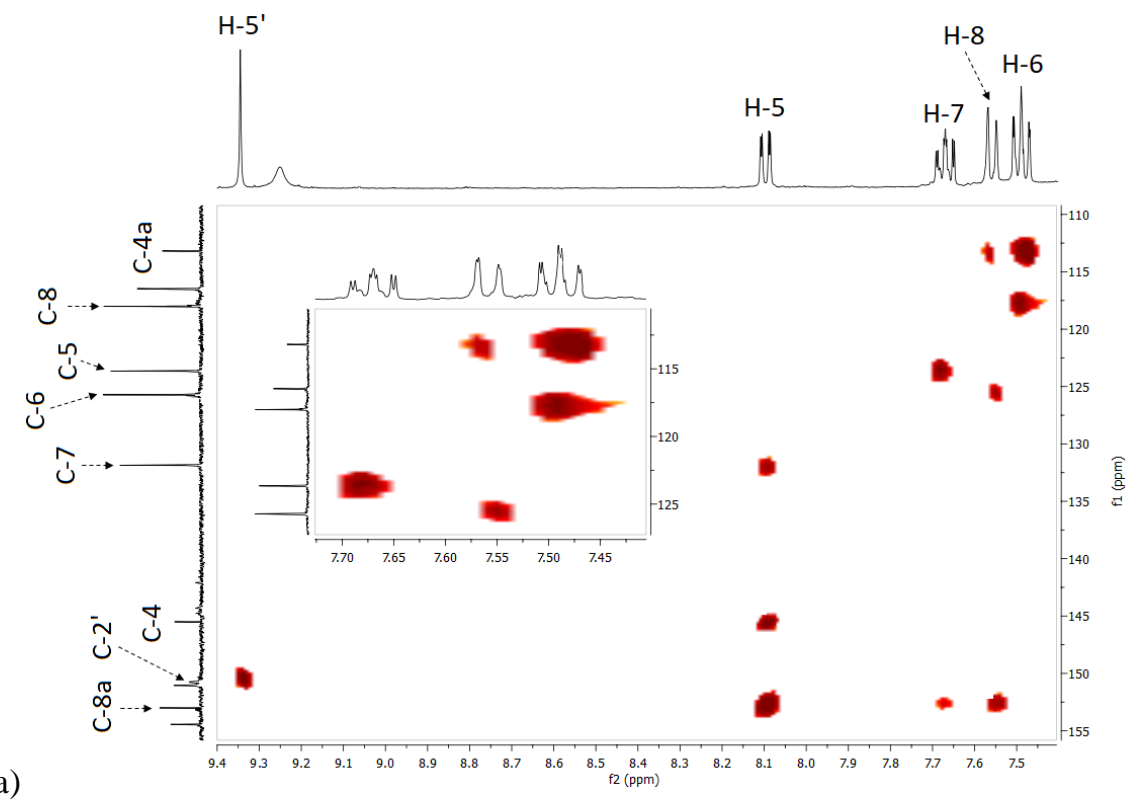

b)

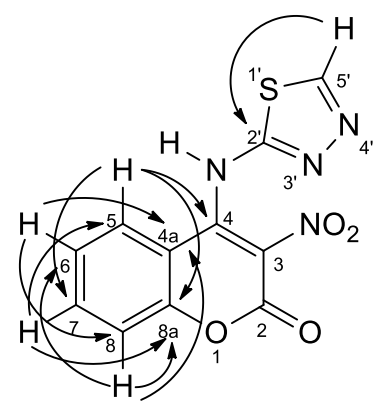

Figure 4. HMBC a) spectrum and b) correlations of compound (5). 
In this way, the chemical shifts of all hydrogen and carbon atoms were determined, except for carbons at position C-2 and $\mathrm{C}-3$, which showed no correlation in all of these two-dimensional NMR spectra. The two last unassigned signals in the ${ }^{13} \mathrm{C} N M R$ spectrum at 154.4 and 116.5 ppm (Fig. 5) were attributed to the $\mathrm{C}-2$ and $\mathrm{C}-3$, respectively, based on the expected values and compared with similar compounds of previous studies (Dekić et al, 2010; Dekić et al., 2016).

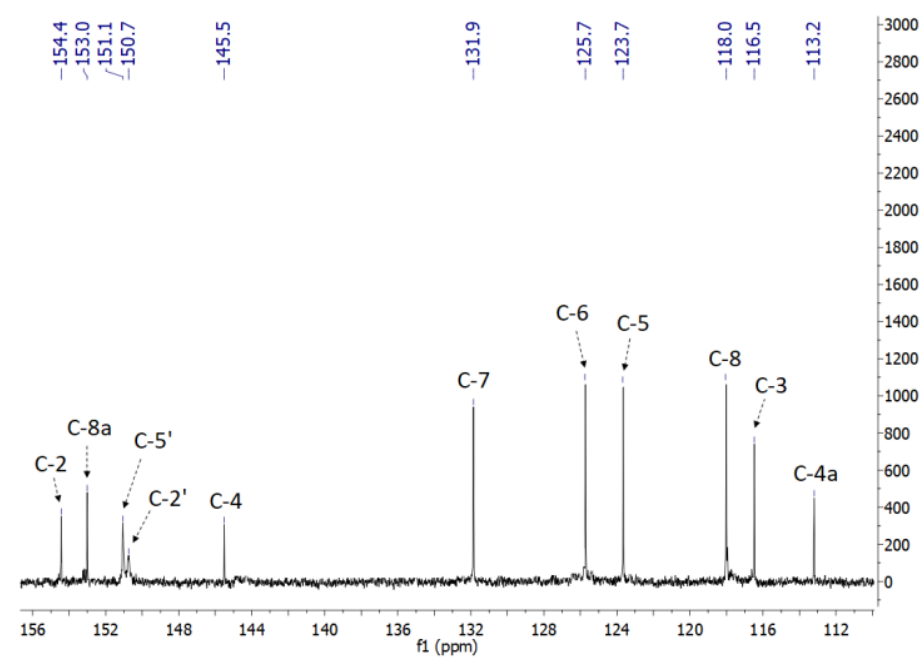

Figure 5. ${ }^{13} \mathrm{C} \mathrm{NMR}\left(\mathrm{CDCl}_{3}, 100.6 \mathrm{MHz}\right)$ spectrum of compound (5).

\section{DPPH assay}

The DPPH assay is a simple, fast and reliable method for determining the antioxidant activity of the compounds. The percentage inhibition of DPPH radicals, depending on the concentration of the tested compound (5), is showed at Fig. 6. Also, the $\mathrm{IC}_{50}$ value for the tested compound was determined, with the amount of $596.7 \pm 0.3 \mu \mathrm{g} / \mathrm{ml}$.

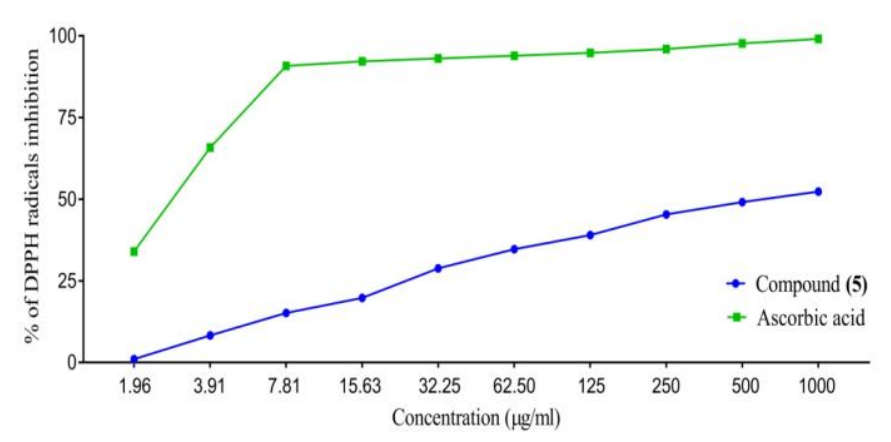

Figure 6. Percentage of inhibition (\%) of DPPH radical depending on the concentration of the tested compound. Ascorbic acid was used as a positive control.

Ascorbic acid, known as an exceptional antioxidant, inhibits $50 \%$ of the DPPH radicals at a concentration of 3.0 \pm 0.1 $\mu \mathrm{g} / \mathrm{ml}$. By comparing the result obtained for the tested compound with the result for ascorbic acid, it can be concluded that the tested compound showed a very good antioxidant potential.

\section{CONCLUSION}

Briefly, synthesis, spectral characterization and antioxidant activity of the new coumarin derivative 4-((1,3,4-thiadiazol-2yl)amino)-3-nitro- $2 H$-chromene-2-one, is described. The structure of the synthesized compound was confirmed by the complete assignment of ${ }^{1} \mathrm{H}$ and ${ }^{13} \mathrm{C}$ NMR spectra, based on data obtained by $1 \mathrm{D}$ and 2D NMR techniques. Determination of antioxidant activity was performed by DPPH assay. The tested compound showed a good antioxidant potential, which provides a strong basis for further research.

\section{ACKNOWLEDGMENTS}

This work was financially supported by the Ministry of Education, Science and Technological Development of Serbia [Project No. 172061 and 45022].

\section{REFERENCES}

Aiyelabola, T., Akinkunmi, E., Obuotor, E., Olawuni, I., Isabirye, D., \& Jordaan, J. 2017. Synthesis Characterization and Biological Activities of Coordination Compounds of 4Hydroxy-3-nitro-2 $\mathrm{H}$-chromen-2-one and Its Aminoethanoic Acid and Pyrrolidine-2-carboxylic Acid Mixed Ligand Complexes. Bioinorganic Chemistry and Applications, pp. 19. doi:10.1155/2017/6426747

Al-Amiery, A.A., Kadhum, A.A.H., \& Mohamad, A.B. 2012. Antifungal Activities of New Coumarins. Molecules, 17(5), pp. 5713-5723. doi:10.3390/molecules 17055713

Anand, P., Singh, B., \& Singh, N. 2012. A review on coumarins as acetylcholinesterase inhibitors for Alzheimer's disease. Bioorganic and Medicinal Chemistry, 20(3), pp. 1175-1180. doi:10.1016/j.bmc.2011.12.042

Ayati, A., Oghabi, B. T., Moghimi, S., Esmaeili, R., MajidzadehA, K., Safavi, M., Firoozpour, L., Emami, S., \& Foroumadi, A. 2018. Synthesis and biological evaluation of new coumarins bearing 2,4-diaminothiazole-5-carbonyl moiety. European Journal of Medicinal Chemistry, 155, pp. 483-491. doi:10.1016/j.ejmech.2018.06.015

Bansal, Y., Sethi, P., \& Bansal, G. 2013. Coumarin: a potential nucleus for anti-inflammatory molecules. Medicinal Chemistry Research, 22(7), pp. 3049-3060. doi:10.1007/s00044-012-0321-6

Braca, A., De Tommasi, N., Bari, L. D., Pizza, C., Politi, M., \& Morelli, I. 2001. Antioxidant Principles from Bauhinia $t$ arapotensis. Journal of Natural Products, 64(7), pp. 892-895. doi:10.1021/np0100845

Danis, O., Yuce-Dursun, B., Gunduz, C., Ogan, A., Sener, G., Bulut, M., \& Yarat, A. 2011. Synthesis of 3-amino-4hydroxy coumarin and dihydroxy-phenyl coumarins as novel anticoagulants. Arzneimittelforschung, 60(10), pp. 617-620. doi:10.1055/s-0031-1296335

Dekić, B., Dekić, V., Radulović, N., Vukićević, R., \& Palić, R. 2010. Synthesis of new antimicrobial 4-aminosubstituted 3- 
nitrocoumarins. Chemical Papers, 64(3). doi:10.2478/s11696010-0004-Z

Dekić, B., Radulović, N., Ristić, M., \& Dekić, V. 2016. The synthesis and NMR spectral assignments of 3-nitro-4-((6nitrobenzothiazol-2-yl)amino)-2H-chromen-2-one. The University Thought - Publication in Natural Sciences, 6(1), pp. 32-38. doi:10.5937/univtho6-10634

Dekić, V., Radulović, N., Vukićević, R., Dekić, B., Skropeta, D., $\&$ Palić, R. 2010. Complete assignment of the $1 \mathrm{H}$ and $13 \mathrm{C}$ NMR spectra of antimicrobial 4-arylamino- 3-nitrocoumarin derivatives. Magnetic Resonance in Chemistry, 48(11), pp. 896-902. doi:10.1002/mrc.2681

Fylaktakidou, K., Hadjipavlou-Litina, D., Litinas, K., \& Nicolaides, D. 2004. Natural and Synthetic Coumarin Derivatives with Anti-Inflammatory / Antioxidant Activities. Current Pharmaceutical Design, 10(30), pp. 38133833. doi:10.2174/1381612043382710

Finn, G. J., Kenealy, E., Creaven, B. S., \& Egan, D. A. 2002. In vitro cytotoxic potential and mechanism of action of selected coumarins, using human renal cell lines. Cancer Letters, 183(1), pp. 61-68. doi:10.1016/s0304-3835(02)00102-7

Hadjipavlou-Litina, D., Kontogiorgis, C., Pontiki, E., Dakanali, M., Akoumianaki, A., \& Katerinopoulos, H. E. 2007. Antiinflammatory and antioxidant activity of coumarins designed as potential fluorescent zinc sensors. Journal of Enzyme Inhibition and Medicinal Chemistry, 22(3), pp. 287-292. doi:10.1080/14756360601073914

Kaljaj, V., Trkovnik, M., \& Stefanović-Kaljaj, L. 1987. Synthesis of new heterocyclocoumarins starting with 3cyano-4-chlorocoumarin. Journal of the Serbian Chemical Society, 52(4), pp. 183-185.

Kostova, I., Raleva, S., Genova, P., \& Argirova, R. 2006. Structure-Activity Relationships of Synthetic Coumarins as HIV-1 Inhibitors. Bioinorganic Chemistry and Applications, pp. 1-9. doi:10.1155/bca/2006/68274

Kotaiah, Y., Nagaraju, K., Harikrishna, N., Venkata, R. C., Yamini, L., \& Vijjulatha, M. 2014. Synthesis, docking and evaluation of antioxidant and antimicrobial activities of novel 1,2,4-triazolo[3,4-b][1,3,4]thiadiazol-6-yl)selenopheno[2,3-d] pyrimidines. European Journal of Medicinal Chemistry, 75, pp. 195-202. doi:10.1016/j.ejmech.2014.01.006

Manojkumar, P., Ravi, T., \& Subbuchettiar, G. 2009. Synthesis of coumarin heterocyclic derivatives with antioxidant activity and in vitro cytotoxic activity against tumour cells. Acta Pharmaceutica, 59(2), pp. 159-170. doi:10.2478/v10007-0090018-7

Naik, N. S., Shastri, L. A., Joshi, S. D., Dixit, S. R., Chougala, B. M., Samundeeswari, S., Holiyachi, M., Shaikh, F., Madar, J., Kulkarni, R., \& Sunagar, V. 2017. 3,4-Dihydropyrimidinonecoumarin analogues as a new class of selective agent against S. aureus: Synthesis, biological evaluation and molecular modelling study. Bioorganic and Medicinal Chemistry, 25(4), pp. 1413-1422. doi:10.1016/j.bmc.2017.01.001

Nofal, Z., El-Zahar, M., \& Abd, E. S. 2000. Novel Coumarin Derivatives with Expected Biological Activity. Molecules, 5(12), pp. 99-113. doi:10.3390/50200099

Parfënov, É. A., \& Smirnov, L. S. 1991. Heterocyclic bioantioxidants. 2. Interaction of 3-nitro-4-substituted coumarins with mercaptans. Chemistry of Heterocyclic Compounds, 27(11), pp. 1190-1192. doi:10.1007/bf00471742

Pasqualotto, A. C., Thiele, K. O., \& Goldani, L. Z. 2010. Novel triazole antifungal drugs: focus on isavuconazole, ravuconazole and albaconazole. Current Opinion in Investigational Drugs, 11, pp. 165-174.

Piazzi, L., Cavalli, A., Colizzi, F., Belluti, F., Bartolini, M., Mancinni, F., Recanatini, M., Andrisana, V., \& Rampa, A. 2008. Multi-target-directed coumarin derivatives: hAChE and BACE1 inhibitors as potential anti-Alzheimer compounds. Bioorganic and Medicinal Chemistry Letters, 18(1), pp. 423426. doi:10.1016/j.bmcl.2007.09.100

Radulović, N., Stojanović-Radić, Z., Stojanović, P., Stojanović, N., Dekić, V., \& Dekić, B. 2015. A small library of 4 (alkylamino)-3-nitrocoumarin derivatives with potent antimicrobial activity against gastrointestinal pathogens. Journal of the Serbian Chemical Society, 80(3), pp. 315-327. doi:10.2298/jsc140619085r

Savel'ev, V. L., Artamonova, O. S., Troitskaya, V. S., Vinokurov, V. G., \& Zagorevskii, V. A. 1973. Investigations of pyrans and related compounds. Khimiya Geterotsiklicheskikh Soedinenii, 9(7), pp. 816-820. doi:10.1007/bf00471556

Stefanachi, A., Leonetti, F., Pisani, L., Catto, M., \& Carotti, A. 2018. Coumarin: A Natural, Privileged and Versatile Scaffold for Bioactive Compounds. Molecules, 23(2), p. 250. doi:10.3390/molecules23020250

Su, C., Mouscadet, J., Chiang, C., Tsai, H., \& Hsu, L. 2006. HIV-1 Integrase Inhibition of Biscoumarin Analogues. Chemical and pharmaceutical bulletin, 54(5), pp. 682-686. doi:10.1248/cpb.54.682

Vaso, K., Behrami, A., \& Krasniqi, I. 2010. Antibacterial Activity of Compounds Synthesized From 4-Chloro-3-nitro2H-[1]-benzopyran-2-one. Asian Journal of Chemistry, 22(9), pp. 7313-7317.

Venugopala, K. N., Rashmi, V., \& Odhav, B. 2013. Review on Natural Coumarin Lead Compounds for Their Pharmacological Activity. BioMed Research International, pp. 1-14. doi:10.1155/2013/963248

Yeh, J. Y., Coumar, M. S., Horng, J. T., Shiao, H. Y., Kuo, F. M., Lee, H. L., Chen, I. C., Chang, C. W., Tang, W. F., Tseng, S. N., Chen, C. J., Shih, S. R., Hsu, J. T., Liao, C. C., Chao, Y. S., \& Hsieh, H. P. 2010. Anti-Influenza Drug Discovery: Structure-Activity Relationship and Mechanistic Insight into Novel Angelicin Derivatives. Journal of Medicinal Chemistry, 53(4), pp. 1519-1533. doi:10.1021/jm901570x

Yu, D., Suzuki, M., Xie, L., Morris-Natschke, S. L., \& Lee, K. 2003. Recent progress in the development of coumarin derivatives as potent anti-HIV agents. Medicinal Research Reviews, 23(3), pp. 322-345. doi:10.1002/med.10034

Zaki, R. M., Elossaily, Y. A., \& Kamal, E. A. M. 2012. Synthesis and antimicrobial activity of novel benzo[f]coumarin compounds. Russian Journal of Bioorganic Chemistry, 38(6), pp. 639-646. doi:10.1134/s1068162012040152 